\title{
Perilaku Murid Sekolah Dasar Kelas III Sampai Kelas VI Tentang Mencuci Tangan di SDN 017 Di Kelurahan Buluh Kasap Kecamatan Dumai Timur Kota Dumai Tahun 2018
}

\author{
Julimar \\ Nursing departement of Akademi Keperawatan Sri Bunga Tanjung Dumai \\ Correspondence E-mail; imaraslya@gmail.com
}

\begin{abstract}
Many children do not wash their hands before eating, so that the bacteria can result in hand with food will be brought in through the mouth and throat to the digestive tract so that the occurrence of an initial survey pencernaan.Based o $n$ the survey that has been done at SD 017 Kelurahan Buluh Kasap Kota Dumai. Most students take hand washing not matching true procedures. The purpose of the research to Description Of The Behavior Of The Primary School Students In Hand washing SDN 017 Buluh Kasap Kota Dumai Tahun 2018. This is a descriptive study conducted on students in grade III and VI SD 017 Buluh Kasap Kota Dumai. The population is all elementary students in grades III through grade VI. Sampling technique with accidental sampling, with a sample of 43 people. Data collection tool used was koesioner and observation sheets. Analysis of the data used univariate data analysis. The results obtained over half (88.3\%) of respondents had a high level of knowledge about hand washing, half (88.3\%) of respondents have a positive attitude about hand washing, and over half (53.4\%) of respondents have either no action about hand washing. In order for the implementation of hand washing behavior expected for elementary school students in order to make policy regarding hand washing, controlling, providing motivation for elementary students 19 olo desert village about handwashing, and complete facilities and infrastructure, including the provision of hand soap and paper towels or clean towel.
\end{abstract}

\section{Abstrak}

Banyak anak sekolah tidak melakukan cuci tangan, sehingga mengakibatkan bakteri yang ada di tangan akan dibawa masuk bersama makanan melalui mulut dan tenggorokan sampai ke dalam saluran pencernaan sehingga terjadinya suatu penyakit saluran pencernaan. Berdasarkan survei awal yang peneliti lakukan di SDN 017 Buluh Kasap Kota Dumai bahwa sebagian murid SD melakukan cuci tangan tidak sesuai dengan teknik cuci tangan yang benar. Tujuan penelitian ini untuk mengetahui Gambaran Perilaku Murid Tentang Mencuci Tangan.di SDN 017 Buluh Kasap Kota Dumai Tahun 2018. Penelitian ini di lakukan pada tanggal 14-18 april 2018,Penelitian ini bersifat deskriptif dilakukan pada murid kelas III sampai kelas IV SD 017 Buluh Kasap Kota Dumai. Populasi adalah seluruh murid SD 017 Buluh Kasap Kota Dumai kelas III sampai kelas VI. Teknik pengambilan sampel dengan cara accidental sampling, dengan jumlah sampel 43 orang murid. Alat pengumpulan data yang digunakan adalah kuesioner dan lembaran observasi.. data dianalisis menggunakan analisa data univariat. Hasil penelitian didapatkan lebih separuh $(88,3 \%)$ responden memiliki tingkat pengetahuan tinggi tentang mencuci tangan, separuh (88,3\%) responden memiliki sikap positif tentang mencuci tangan, dan lebih separuh $(53,4 \%)$ responden memiliki tindakan tidak baik tentang cuci tangan. Agar terlaksananya perilaku mencuci tangan bagi murid SD diharapkan pihak sekolah agar dapat membuat kebijakan terkait perilaku mencuci tangan, melakukan pengontrolan, memberikan motivasi bagi murid SD 017 Buluh Kasap Kota Dumai tentang perilaku cuci tangan,serta melengkapi sarana dan prasarananya yang meliputi penyediaan sabun cuci tangan dan tisu atau handuk bersih .

Kata Kunci: perilaku, cuci tangan

\section{Introduction}

Masalah kesehatan anak di setiap negara memiliki perbedaan. Hal ini terjadi karena perbedaan lingkungan yang mempengaruhinya. Dalam garis besarnya, masalah kesehatan tersebut dapat dikelompokkan menjadi 2 kategori, yaitu masalah yang ada di negara maju dan di negara yang sedang berkembang termasuk Indonesia. Adapun masalah kesehatan yang terdapat di negara berkembang seperti penyakit infeksi, parasit dan kurang gizi. Kesehatan merupakan investasi untuk meningkatkan produktivitas kerja guna meningkatkan kualitas hidup manusia. Perilaku hidup bersih dan sehat merupakan cerminan pola hidup yang senantiasa memperhatikan dan menjaga kesehatan

Received: 3 Agust 2020, Accepted : October 2020 - Jurnal Photon Vol.11 No.1

DOI : https://doi.org/10.37859/jp.v17i1.2161

PHOTON is licensed under a Creative Commons Attribution-ShareAlike 4.0 International License 
seluruh anggota keluarga. Pola hidup bersih dan sehat harus ditanamkan sedini mungkin agar menjadi kebiasaan positif dalam memelihara kesehatan (Proverawati, 2012).

Tangan adalah bagian tubuh yang paling sering dipakai untuk melakukan kontak dengan dunia luar. Dengan mencuci tangan, berbagai risiko penularan penyakit seperti diare, difteri, infeksi saluran pernapasan atas (ISPA), disentri dan berbagai penyakit lain bisa terhindarkan. "Banyak penyakit infeksi yang bisa kita hindari dengan cuci tangan. Flu burung pun juga bisa kita hindari dengan cuci tangan. Tangan sering kali menjadi agen yang membawa kuman dan menyebabkan pathogen berpindah dari satu orang keorang lain,baik dengan kontak langsung ataupun kontak tidak langsung (menggunakan permukaan-permukaan lain seperti handuk, gelas). Tangan yang bersentuhan langsung dengan kotoran manusia dan binatang, ataupun cairan tubuh lain (seperti ingus, dan makanan/minuman yang terkontaminasi saat tidak dicuci dengan sabun dapat memindahkan bakteri, virus, dan parasit pada orang lain yang tidak sadar bahwa dirinya sedang ditularkan (Mujiyanto, 2009).

Menurut Sigmund Freud (Irwanto, 2002), anak usia 12 tahun sering disebut dengan masa anak pertengahan atau laten yaitu masa tenang dan nyaman, walau anak mengalami perkembangan pesat pada aspek motorik dan kognitif. Anak laki-laki lebih banyak bergaul dengan teman sejenis, demikian pula dengan anak perempuan. Oleh karena itu, fase ini disebut juga periode homoseksual alamiah. Anak mencari figur ideal diantara orang dewasa berjenis kelamin sama dengannya. Masa sekolah atau masa prapubertas, wanita 6-10 tahun dan laki-laki 8-12 tahun. Pertumbuhan lebih cepat dibandingkan masa prasekolah, keterampilan dan intelektual makin berkembang, senang bermain dan berkelompok dengan teman yang berjenis kelamin yang sama (Narendra, 2002).

Curtis and Cairncross (2003) didapatkan hasil bahwa perilaku cuci tangan pakai sabun (CTPS) khususnya setelah kontak dengan feses ketika ke jamban dan membantu anak ke jamban, dapat menurunkan insiden diare hingga 42-47\%. Perilaku CTPS juga dikatakan dapat menurunkan transmisi ISPA hingga lebih dari 30\% ini diperoleh dari kajian yang dilakukan oleh Rabie and Curtis (2005). Di lain pihak, Unicef menyatakan bahwa CTPS dapat menurunkan 50\% insidens flu burung. Beberapa kajian ini menunjukan bahwa intervensi CTPS dianggap sebagai pilihan perilaku yang efektif untuk pencegahan berbagai penyakit menular. Artinya, sekitar satu juta anak di dunia dapat diselamatkan tiap tahun dengan cuci tangan. Hanya saja ada yang perlu diperhatikan dalam prosesnya, yaitu harus menggunakan sabun dan membilas tangan menggunakan air mengalir. Menurut Curtis \& Cairncross, tanpa sabun, bakteri dan virus tidak akan hilang. Air hanya sebatas menghilangkan kotoran yang tampak, tetapi tak menghilangkan cemaran mikrobiologis yang tidak tampak.

Dapat disimpulkan bahwa peran pendidikan kesehatan adalah melakukan intervensi faktor perilaku sehingga perilaku individu, kelompok atau masyarakat sesuai dengan nilai kesehatan. Dengan kata lain, pendidikan kesehatan adalah suatu usaha untuk menyediakan kondisi psikologis dari sasaran agar mereka berperilaku sesuai dengan tuntutan nilai-nilai kesehatan.

Berdasarkan survei awal yang peneliti temukan di lapangan pada tanggal 28 Januari 2018 Sebagian murid SDN 017 Kelurahan Buluh Kasap Kota Dumai sudah mengetahui cuci tangan secara umum namun kenyataan yang ditemui dilapangan mencuci tangan yang dilakukan tidak sesuai dengan cara cuci tangan yang diajarkan oleh guru disekolah dan tata cara cuci tangan yang benar. Dan Setelah dilakukan wawancara dengan beberapa guru di SD 017 Kelurahan Buluh Kasap Kota Dumai menyatakan bahwa dalam 1 bulan terakhir ada sekitar 10 anak yang mengalami demam dan diare.

Peneliti melakukan wawancara dan observasi dari 10 responden yang diteliti, 2 siswa melakukan cuci tangan setelah bermain disebabkan sudah membiasakan cuci tangan, 4 siswa jarang melakukan cuci tangan sebelum dan sesudah makan atau jajan dengan alasan mereka malas, dan 3 siswa tidak

Received: 3 Agust 2020, Accepted : October 2020 - Jurnal Photon Vol.11 No.1

DOI : https://doi.org/10.37859/jp.v17i1.2161

PHOTON is licensed under a Creative Commons Attribution-ShareAlike 4.0 International License 
pernah melakukan cuci tangan setelah buang air kecil atau buang air besar disebabkan mereka tidak mengetahui dan tidak membiasakan melakukan kegiatan tersebut,dan 1 siswa jarang melakukan cuci tangan sebelum dan sesudah melakukan tindakan seperti sebelum belajar,atau melakukan kegiatan yang lain. Peneliti mengambil SDN 017 Kelurahan Buluh Kasap disebabkan karena SD tersebut memiliki fasiltas yang sesuai dengan standar kesehatan dan selain itu peneliti juga melihat fasilitas yang tersedia belum sepenuhnya dipakai oleh para murid.

\section{The Methods}

Jenis penelitian yang digunakan adalah deskriptif yang bertujuan yaitu untuk mendapatkan gambaran perilaku murid SDN 017 Kelurahan Buluh Kasap Kota Dumai tentang mencuci tangan. Sampel merupakan sebagian yang diambil dari keseluruhan objek yang diteliti dan mewakili seluruh populasi (Soekidjo, Notoatmojo, 2002: 79). Dalam penelitian ini penulis menggunakan accidental sampling dari seluruh jumlah murid kelas III sampai kelas IV SDN 017 Kelurahan Buluh Kasap Kota Dumai yaitu sampel yang ada saat penelitian

\section{Result and Discussion}

Pada tabel 1 dapat dilihat bahwa lebih separuh (88,3\%) responden memiliki tingkat pengetahuan tinggi tentang cuci tangan

Tabel 1. Distribusi Frekuensi Responden Berdasarkan Tingkat Pengetahuan Tentang Mencuci Tangan SDN 017 Kelurahan Buluh Kasap Kota Dumai

\begin{tabular}{|l|c|c|}
\hline Pengetahuan & F & $\mathbf{\%}$ \\
\hline Tinggi & 38 & $88,3 \%$ \\
\hline Rendah & 5 & $11,6 \%$ \\
\hline Jumlah & $\mathbf{4 3}$ orang & $\mathbf{1 0 0 \%}$ \\
\hline
\end{tabular}

Menurut Sokidjo Notoadmodjo (2002) menyebutkan bahwa pengetahuan adalah meupakan hasil tahu dan ini terjadi setelah penginderaan terhadap suatu objek tertentu. Penginderaan terjadi melalui panca indera manusia yakni indera penglihatan, pendengaran, penciuman, rasa dan raba, sebagian besar pengetahuan manusia diperoleh dari mata dan telinga. Menurut Sokidjo Notoadmodjo (2003) menyebutkan bahwa pengetahuan atau kognitif merupakan domain yang sangat penting terbentuknya tindakan seseorang, dari pengalaman dan penelitian ini terbukti bahwa perilaku didasari oleh pengetahuan akan lebih langgeng dari perilaku yang tidak didasari dari pengalaman. Dari hasil analisa jawaban responden terhadap pertanyaan dalam kuisioner didapatkan bahwa responden cukup mengetahui tujuan dan teknik mencuci tangan yang benar. Hal ini terihat rata - rata jawaban responden berkisar 60 - $90 \%$. Disamping itu jawaban responden sangat dipengaruhi oleh tingkat pendidikan yang telah dijalani hampir separuh $(46,5 \%)$ berada pada kelas V dan VI dengan tingginya pendidikan murid maka semakin tinggi pula wawasan berfikirnya sehingga akan banyak informasi yang dapat diserapnya.

Received: 3 Agust 2020, Accepted : October 2020 - Jurnal Photon Vol.11 No.1

DOI : https://doi.org/10.37859/jp.v17i1.2161

PHOTON is licensed under a Creative Commons Attribution-ShareAlike 4.0 International License 
Pada tabel 2 dapat dilihat bahwa lebih separuh (88,3 \%) responden memiliki sikap positif tentang cuci tangan

Tabel 2. Distribusi Frekuensi Responden Berdasarkan Sikap Tentang Mencuci Tangan SDN 017 Kelurahan Buluh Kasap Kota Dumai

\begin{tabular}{|l|c|c|}
\hline Sikap & F & $\mathbf{\%}$ \\
\hline Positif & 38 & $88,3 \%$ \\
\hline Negatif & 5 & $11,6 \%$ \\
\hline Jumlah & $\mathbf{4 3}$ orang & $\mathbf{1 0 0 \%}$ \\
\hline
\end{tabular}

Sikap merupakan reaksi atau respon seseorang yang masih tertutup terhadap suatu stimulus atau objek (Notoatmojo,2013:124) manifestasi dari sikap tidak dapat langsung dilihat,tetapi hanya dapat di tafsirkan terlebih dahulu dari prilaku tertutup. Sikap secara nyata mempunyai konotasi adanya kesesuaian sehari-sehari yang bersifat emosional terhadap suatu stimulus.

Pada tabel 3 dapat dilihat bahwa lebih separuh $(53,4 \%)$ responden memiliki tindakan tidak baik tentang cuci tangan

Tabel 3. Distribusi Frekuensi Responden Berdasarkan Tindakan Mencuci Tangan SDN 017 Kelurahan Buluh Kasap Kota Dumai

\begin{tabular}{|l|l|l|}
\hline Tindakan & $\mathbf{F}$ & $\mathbf{\%}$ \\
\hline Baik & 20 & $46,5 \%$ \\
\hline Tidak baik & 23 & $53,4 \%$ \\
\hline Jumlah & $\mathbf{4 3}$ orang & $\mathbf{1 0 0 \%}$ \\
\hline
\end{tabular}

Tindakan menunjukkan pada sesuatu gerak kegiatan yang sengaja dilakukan dengan tujuan tertentu (Arikunto, 2002). Suatu sikap belum optimis terwujud dalam suatu tindakan (overt behavior). Untuk mewujudkan sikap menjadi suatu perbuatan nyata diperlukan factor pendukung atau suatu kondisi yang memungkinkan antara lain fasilitas.

Nurbaiti (2007) mengemukakan tindakan dapat di pengaruhi oleh faktor internal dan faktor external seperti usia, pendidikan, pengetahuan dan masa kerja didukung oleh Notoadmodjo yang mengemukakan bahwa faktor yang mempengaruhi tindakan adalah pendidikan, usia, dan motivasi.

\section{Conclusion}

Hasil penelituian menunjukkan: Lebih separuh responden memiliki tingkat pengetahuan tinggi tentang mencuci tangan, Lebih separuh responden memiliki sikap positif tentang mencuci tangan, Lebih separuh responden memiliki tindakan tidak baik tentang cuci tangan. Berdasarkan hal diatas dapat disarankan agar terlaksananya perilaku mencuci tangan bagi murid SD diharapkan pihak sekolah agar dapat membuat kebijakan terkait pencucian tangan,, melakukan pengontrolan,

Received: 3 Agust 2020, Accepted : October 2020 - Jurnal Photon Vol.11 No.1

DOI : https://doi.org/10.37859/jp.v17i1.2161

PHOTON is licensed under a Creative Commons Attribution-ShareAlike 4.0 International License 
memberikan motifasi bagi murid tentang perilaku cuci tangan. Serta melengkapi sarana dan prasarananya yang meliputi penyediaan sabun cuci tangan dan tisu atau handuk bersih .

\section{References}

A.Poter, Patricia, Pery, (2002), Keterampilan dan Prosedur Dasar, Mosby:Elsevier Science.Media Sehat Edisi 4 terbitan Januari 2010

Arikunto, S. (2000). Manajemen Penelitian. Jakarta: Rineka Cipta.

(2006),prosedur penelitian. jakarta:PT Rineka Cipta.

Kemenkes. (2013). Informasi Pengendalian Penyakit Menular dan Penyehatan Lingkungan. Jakarta : Depkes RI.

(2010), Panduan Perencanaan Pelaksanaan Hari Cuci Tangan Pakai sabun Gobel,yanti (2009).Masalah kesehatan Anak Usia Sekolah.Catatan hari anak nasional 23 Juli Hidayat, A. Aziz Alimul. (2007). Pengantar Ilmu Keperawatan Anak I. Jakarta: Salemba Medika — (2005), Pengantar Ilmu Keperawatan Anak I, Jakarta Salemba Medika

Hidayat A. Aziz Alimul,Uliyah M. (2004). buku saku pratikum kebutuhan dasar manusia, EGC, Jakarta Kusyati, Eni. (2006). Keterampilan dan Prosedur Laboratorium. Jakarta: Buku Kedokteran EGC. Nasrul Effendi, (1998), Dasar-Dasar Kesehatan Masyarakat, Jakarta : EGC.

Notoatmodjo, Soekidjo. (2000). MetodologiPenelitianKesehatan. Jakarta :Rineka Cipta

Notoatodjo, Soekidjo (2003). Prinsip-Prinsip Dasar Ilmu Kesehatan Masyarakat. Jakarta : Rineka Cipta.

(2005), Metodologi Penelitihan Kesehatan, Jakarta: PT. RinekaCipta. (2007). Promosi Kesehatan dan Ilmu Prilaku. Jakarta : Rineka Cipta

Potter Pery (2005), Fundamental of Nursing, Jakarta: EGC. 